\title{
Cyclotella hinziae sp. nov. - a small Cyclotella (Bacillariophyceae) from subalpi- ne lake Schliersee (Bavaria, Germany)
}

\author{
Václav HouK ${ }^{1 *}$, Claudia KöNIG ${ }^{2} \&$ Rolf $\mathrm{KLEE}^{3}$ \\ ${ }^{1}$ Institute of Botany, Czech Academy of Sciences, Dukelská 135, CZ-379 82 Třebon̆, Czech Republic; "Corre- \\ sponding author's e-mail: vaclav.houk@ibot.cas.cz \\ ${ }^{2}$ Bavarian Environmental Agency, Demollstrasse 31, D-82407 Wielenbach, Germany \\ ${ }^{3}$ Regener Str. 32, D-94249 Bodenmais, Germany
}

\begin{abstract}
A small Cyclotella species (Thalassiosiraceae) from a subalpine lake Schliersee (Bavaria, Germany) is described. The species has characteristic valve morphology different from this of the other similar taxa. It differs from them especially with the presence of radially arranged ghost structures in the valve central part and with the presence and low number of transversal trabeculae inside the alveolus - maximally 6 in $1 \mu \mathrm{m}$. The valve morphology and ultrastructure of this taxon is described and its new name, Cyclotella hinziae, is proposed. Its valve morphology is compared and discussed with this of other similar taxa.
\end{abstract}

Key words: Lake Schliersee, Thalassiosiraceae, freshwater centric diatoms, valve morphology, valve ultrastructure

\section{INTRODUCTION}

The genus Cyclotella (KüTZING) BRÉBISSON belongs among the most frequently quoted genus of the Family Stephanodiscaceae (Round et al. 1990), having about 300 till now described taxa, fossil as well as recent (see e.g. Index Nominum Algarum by P. Silva). Their recent representatives live mostly in freshwater phytoplankton or littoral and some of them are often accepted as important indicators of environmental conditions in limnology. They live solitary or they can create shorter or longer loose or more or less tight chains of cells, sometimes the cells are enclosed in mucous sheets (see e.g. Round et al. 1990; Krammer \& Lange-Bertalot 1991; Houk et al. 2010). The identification of the species with the large cells is usually relatively easy, however, in the species with small cells, usually with the valve diameter smaller than $5-7 \mu \mathrm{m}$, is the identification very hard, even in SEM. And just the representatives of this genus with cells of a smaller size often create their maximum of development in spring or autumn in many lakes or slowly running rivers. Among these most often cited taxa belong e.g. Cyclotella comensis Grunow in Van Heurck (e.g. HaUSMann \& LotTer 2001; Scheffler \& Morabito 2003; Scheffler et al. 2005), C. pseudocomensis Scheffler (SCheffler 1994; Scheffler et al. 2003), C. ocellata Pantocsek (PantocseK 1901; Kiss et al. 1999), C. delicatula Hustedt
(Hustedt 1952; Kiss et al. 2007) and C. costei Druart \& Straub (Druart \& Straub 1988). During our investigations of the centric diatom communities in the lake Schliersee in the period 1997-2014 was observed a small Cyclotella taxon with distinctive valve morphology different from this of the other similar, till now described taxa. The valve morphology and ultrastructure of this taxon is described and its new name, Cyclotella hinziae, is proposed. Its valve morphology is compared and discussed with this of other similar taxa.

\section{Materials And Methods}

For the investigation were used Schliersee net plankton samples from 6 May 1997, 5 Nov 2001, 21 Aug 2006, 25 May 2010 and 31 Mar 2014. A core from Lake Schliersee May 2001 taken by R. Klee and J. Müller was also used for description.

Schliersee is a natural lake in Upper Bavaria in the Bavarian Alps. It is located next to the small town of Schliersee in the Miesbach district. The lake is of the glacial origin. Some morphometric and trophy-relevant data.

The raw material was washed in distilled water and cleaned using Hydrogen peroxide/potassium dichromate. For LM-observations the cleaned material was mounted in Naphrax and the LM investigations were carried out on an Olympus BX 51 microscope with UPlanApo $100 \times / 1.35$ Oil Iris objective equipped with a digital camera Olympus DP 
Table 1. Morphometric and trophy-relevant data of the lake

\begin{tabular}{lllllll}
\hline $\begin{array}{l}\text { Surface } \\
\left(\mathbf{k m}^{2}\right)\end{array}$ & $\begin{array}{l}\text { Volume } \\
\left(\mathbf{1 0}^{\mathbf{6}} \mathbf{m}^{\mathbf{3}}\right)\end{array}$ & $\begin{array}{l}\text { Altitude } \\
(\mathbf{m} \text { a.s.l. })\end{array}$ & $\begin{array}{l}\text { Depth } \\
(\mathbf{m})\end{array}$ & $\begin{array}{l}\text { Depth } \\
(\mathbf{m})\end{array}$ & $\begin{array}{l}\mathbf{P}_{\text {tot }} \\
\left(\boldsymbol{\mu g . \mathbf { l } ^ { - 1 }}\right)\end{array}$ & $\begin{array}{l}\text { Chl a } \\
\left(\boldsymbol{\mu g . \mathbf { l } ^ { - 1 }}\right)\end{array}$ \\
\hline 2.22 & 23.13 & 777 & 40.5 & 23.9 & $7-23$ & $<5$ \\
\hline
\end{tabular}

71. For SEM-investigations, material was dried on glass slides, mounted on aluminium stubs and coated with gold by Polaron coating unit E-5000. Hitachi S-3000N and FEI QUANTA 200F electron microscopes were used for SEMinvestigations.

The terminology used is based on Anonymous (1975), Ross et al. 1979 and Theriot \& SERIEyssol (1994). Number of striae in $10 \mu \mathrm{m}$ were determined following Gen$\mathrm{kal}$ (1977), i.e. as the number of striae in $10 \mu \mathrm{m}$ of the valve circumference, not in $10 \mu \mathrm{m}$ of a transect (chord).

\section{Results}

Cyclotella hinziae Houk, KöNIG et KLEE sp. nov. (Figs 1-6, 19-37)

Description: Cells cylindrical, often in chains. Valves circular, 3.5-12 $\mu \mathrm{m}$ in diameter, frustules height mostly between 1.5 and $3.2 \mu \mathrm{m}$. The central area smooth, flat to slightly transversally undulate, often with shallow radial furrows or lines, sometimes with sparsely, \pm radially arranged, circular to elongate pori not penetrating the cell wall. One central fultoportula, externally as a simple large rimmed porus, internally with a short central tube situated opposite to rimoportula, surrounded with (1)2(3) satellite pori. Valve marginal part with the radially arranged striae (alveoli) of nearly equal lengths, 17.5-23 striae in $10 \mu \mathrm{m}$. Alveoli inside with rings of concentrically arranged trabeculae, usually (2)3-6 trabeculae in an alveolus, externally these trabecular rings as smooth crossbars or partitions. Between trabeculae many irregularly arranged small pori penetrating the cell wall. The marginal fultoportulae situated on costae, (3)4-6 costae between them, 4-12 per valve, 2.4-3.7 mfp in $10 \mu \mathrm{m}$. Internally the short central tubes surrounded with two laterally arranged satellite pori, externally they are opened as simple large pori inside small smooth circular fields. A single rimoportula is situated on a costa in the marginal part, internally with a sessile labium, externally as a circular, sometimes radially elongated, simple small porus. Valve surface is without granules.

Initial valves of lenticular shape. Their central part sometimes slightly transversally undulate, sometimes externally with pori not penetrated the cell wall, often with a single central fultoportula.

Holotype: Slide Zu9/93, Lake Schliersee (Germany), plankton 31 March 2014, Diatom Collection of Friedrich Hustedt, Alfred-Wegener-Institut für Polar- und
Meeresforschung, Bremerhaven, Germany.

Isotype: Slide no. A337, Lake Schliersee (Germany), 31 March 2014, Diatom Slides Collection, Department of Botany, Charles University, Prague, Czech Republic.

Type locality: Lake Schliersee (Germany).

Etymology: This taxon is named in honor of Mrs Friedel Hinz, the assistant of long-standing in the Diatom Collection of Friedrich Hustedt, Alfred-Wegener-Institut für Polar- und Meeresforschung, Bremerhaven, Germany.

It differs from the morphologically most similar species $C$. delicatula HustedT with the presence of radially arranged ghost structures in the valve central part and with a lower number of trabeculae in $1 \mu \mathrm{m}$ of the alveolus - maximally 6 in C. hinziae, more than 6 in C. delicatula. From morphologically similar C. arctica GenKal \& KHARITONOV it differs in the structure of the valve central part where $C$. arctica has much coarser, often radially arranged structures there, and in the marginal has alveoli of different lengths (see GENKAL \& Kharitonov 1996, p. 69; GenKal \& Kharitonov 2005, p. 21).

\section{LM Observations (Figs 1-16)}

In the slides the cells occur mostly solitary (Figs 1-16), in the live plankton samples cells in chains consisting of more than 10 cells were often found. Cells are shallow cylinders, with the pervalvar axis much shorter than the valve diameter. Valves were circular, with the diameter $6-12 \mu \mathrm{m}$. The central area takes 0.7 to 0.5 of the valve diameter, with an ill-defined stellate pattern consisting of radially arranged ghost striae (Figs 13-16) with one coarser punctum near the valve centre (Figs 6-13). The marginal zone is radially striated with 18-23 striae (alveolae in SEM) in $10 \mu \mathrm{m}$, striae of nearly equal lengths. The marginal fultoportulae hardly distinguishable in LM (e.g. Figs 9 and 14). Initial cells/ valves have not been observed in LM.

\section{SEM Observations (Figs 17-42)}

Cells cylindrical, often in chains. Valves circular, 3.5-12 $\mu \mathrm{m}$ in diameter, frustules height mostly between 1.5 and $3.2 \mu \mathrm{m}$. The central area is mostly smooth, often with shallow radial furrows or lines (Figs 21, 23, 38, 39), flat to slightly transversally undulate (Figs 21,39 ). Sometimes the valve central part externally with sparsely, \pm radially arranged, circular to elongate pori not penetrating the cell wall (Figs 20, 22, 24). One central fultoportula 
(cfp), externally as a simple large rimmed porus (e.g. Figs 20-24), internally with a short central tube situated opposite to rimoportula (rp), surrounded with (1)2(3) satellite pori (e.g. Figs 27, 30, 32). Valve marginal part consists of the radially arranged alveoli of nearly equal lengths, 17.5-23 alveoli in $10 \mu \mathrm{m}$. Alveoli inside with rings of concentrically arranged trabeculae (Fig. 28, 32), usually (2)3-6 trabeculae in an alveolus (maximally 6 trabeculae in $1 \mu \mathrm{m}$ ), externally these trabecular rings as smooth crossbars or partitions (Figs 25, 26). Between these trabeculae many irregularly arranged small pori penetrating the cell wall (Figs 28, 32). The marginal fultoportulae (mfp) are situated on costae (e.g. Fig. 33), (3)4-6 costae between them, 4-12 per valve, 2.4-3.7 $\mathrm{mfp} / 10 \mu \mathrm{m}$. Internally the short central tubes are surrounded with two laterally arranged satellite pori (Fig. 33 ), externally they are opened as simple large pori inside small smooth circular fields (Fig. 23). A single rimoportula is situated on a costa in the marginal part, internally with a sessile labium (Figs 27, 30, 32, 33), externally as a circular, sometimes radially elongated, simple small porus (Figs 20-22). Granules on the valve surface have never been observed.

Initial valves of hemispherical to rather lenticular shape were also observed (Figs 34-37). Their central part sometimes slightly transversally undulate, sometimes externally with pori not penetrated the cell wall (Fig. 34), often with a single central fultoportula (Fig. 35).

\section{Discussion}

Several small freshwater Cyclotella taxa have been described until now. In their natural populations can be observed cells with the valve diameter smaller than 5 $\mu \mathrm{m}$. Among these taxa belong particularly Cyclotella ocellata PANTOCSEK, C. cretica JoHn et EconomouAmilli, C. tripartita HÅkansson, C. comensis Grunow in VAn Heurck, C. pseudocomensis Scheffler, C. delicatula Hustedt, C. wuethrichiana Druart et Straub, C. costei Druart et Straub and $C$. arctica Genkal et KharitonOv. However, it seems that there are still small Cyclotella taxa which were not described yet, probably just due to their small size. Morphologically the most similar species to $C$. hinziae described here is $C$. delicatula Hustedt, mainly due to the location of internal projections of marginal fultoportulae on not depressed costae. However, it differs from C. delicatu$l a$ with the presence of radially arranged ghost structures in the valve central part and with a lower number of trabeculae in $1 \mu \mathrm{m}$ of the alveolus - maximally 6 in $C$. hinziae sp. nov., more than 6 in C. delicatula. Another morphologically similar small taxon with internal projections of marginal fultoportulae on not depressed costae is $C$. arctica Genkal et Kharitonov. These two species, $C$. hinziae sp. nov. and C. arctica, mutually differ in the structure of the valve central part where $C$. arctica has much coarser, often radially arranged structures there and its marginal part consists of long alveoli of different lengths often running deep to valve center (see GenKal \& Kharitonov 1996, p. 69; Genkal \& Kharitonov 2005, p. 21). Also the striation density of $C$. arctica, 24-32 in $10 \mu \mathrm{m}$ (GENKAL \& Kharitonov 1996, p. 69; Genkal \& Kharitonov 2005, p. 21), differs from $C$. hinziae with 17.5-23 striae in $10 \mu \mathrm{m}$. Other small similar Cyclotella taxa as $C$. comensis Grunow in VAN HeURCK, C. pseudocomensis Scheffler, $C$. wuethrichiana Druart et Straub and $C$. costei Druart et Straub have their internal projections of the marginal fultoportulae situated on depressed costae, and also their structures in the valve central part are of another type (e.g. SCHEFFLER 1994; SCHEFFLER et al. 2005; Houk et al. 2010).

\section{ACKNOWLedgements}

First of all we would like to thank to Martin Mertl and Christian Wagner (Wasserwirschaftsamt Rosenheim, Germany) for collecting the samples. We would like to thank to Dr. Bank Beszteri and Friedel Hinz (Alfred-Wegener-Institut für Polar- und Meeresforschung, Bremerhaven (Germany) for their hospitality and help during our investigations in the Diatom Collection of Friedrich Hustedt. Also we would like to thank to Martina Sendl (Bayer. Landesamt für Umwelt, Wielenbach) for her technical assistance. The investigation was supported by the institutional long-term research plan No. AV0Z60050516, funded by the Academy of Sciences of the Czech Republic.

\section{REFERENCES}

Anonymous (1975): Proposals for a standardisation of diatom terminology and diagnosis. - Nova Hedwigia Beiheft 53: 323-354.

Druart, J.C. \& Straub, F. (1988): Description de deux nouvelles Cyclotelles (Bacillariophyceae) de milieux alcalins et eutrophes: Cyclotella costei nov. sp. et Cyclotella wuethrichiana nov. sp. - Schweizerische Zeitschrift für Hydrologie 50: 182-188.

GenKaL, S.I. (1977): K metodike podschota nektorich taksonomicheskih znachimih strukturnih elementov stvorki u diatomovih vodoroslej sem. Thalassiosiraceae Lebour emend Hasle (Bacillariophyta). - Botanicheskii Zhurnal 62: 848-851 (in Russian).

GenKal, S.I. \& Kharitonov, V.G. (1996): Cyclotella arctica (Bacillariophyta), a new species from the Elghyghytghyn lake (Chukchi Peninsula). - Botanicheskii Zhurnal 81: 69-73 (in Russian).

Genkal, S.I. \& Kharitonov, V.G. (2005): On the morphological variability of Cyclotella arctica (Bacillariophyta). - Botanicheskii Zhurnal 90: 19-22, 2 picture plates (in Russian).

Hausmann, S. \& LotTer, A.F. (2001): Morphological variation within the diatom taxon Cyclotella comensis and its importance for quantitative temperature reconstructions. - Freshwater Biology 46: 1323-1333.

Houk, V.; KleE, R. \& TanaKa, H. (2010): Atlas of freshwater centric diatoms with a brief key and descriptions. Part III, Stephanodiscaceae A: Cyclotella, Tertiarius 

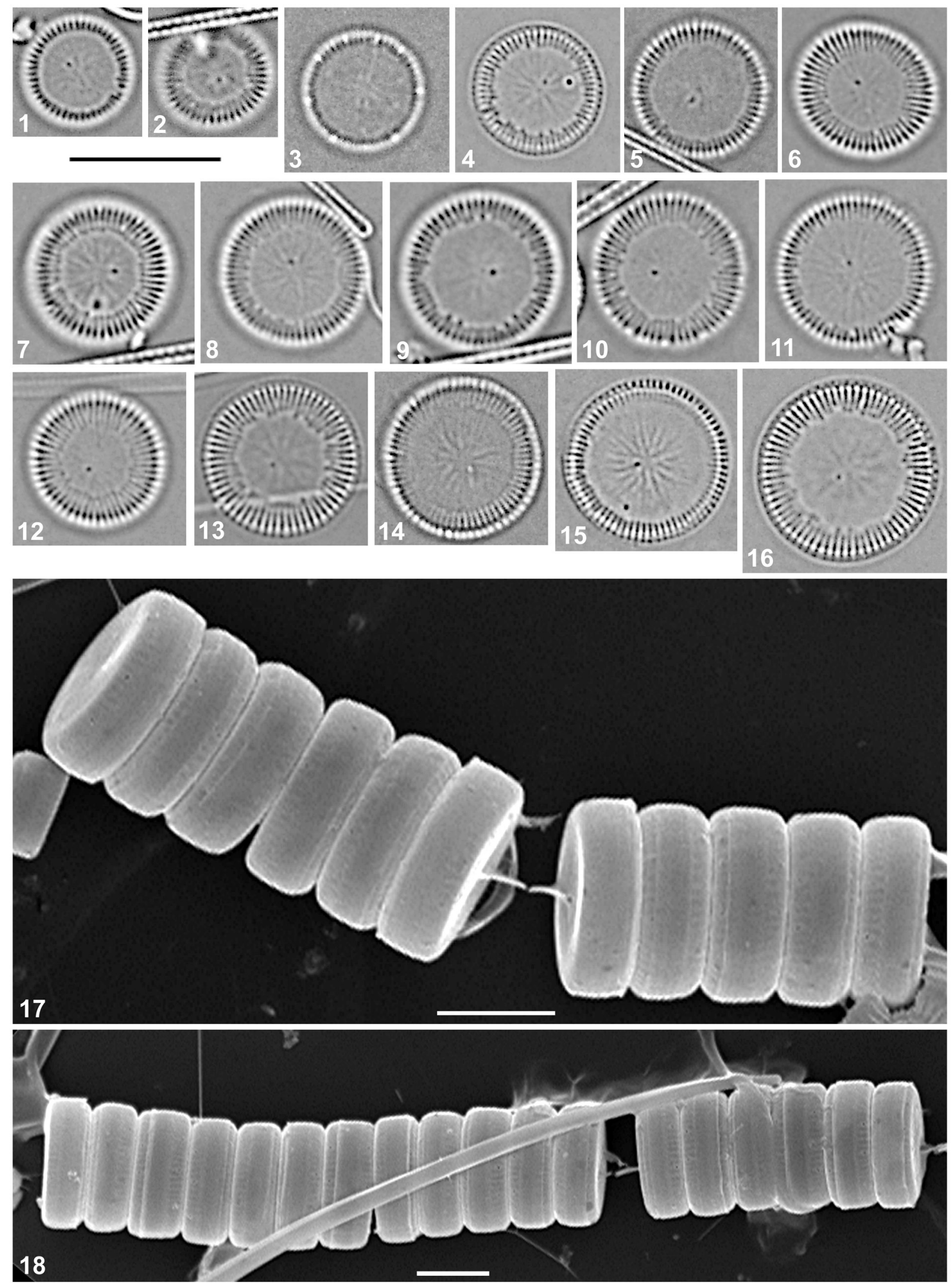

Figs 1-18. Cyclotella hinziae sp. nov.: (1-16) LM, holotype, slide Zu9/93, valve views, Diatom Collection of Friedrich Hustedt, Alfred-Wegener-Institut für Polar- und Meeresforschung, Bremerhaven, Germany, Lake Schliersee (Bavaria, Germany), plankton 31 March 2014, (3, 10, 11, 13-16) valves with a ghost stellate pattern in the central part; $(17,18)$ SEM, girdle views of short chains of living cells, Lake Schliersee (Bavaria, Germany), plankton 6 May 1997. Scale bar $10 \mu \mathrm{m}(1-16), 5 \mu \mathrm{m}(17,18)$. 

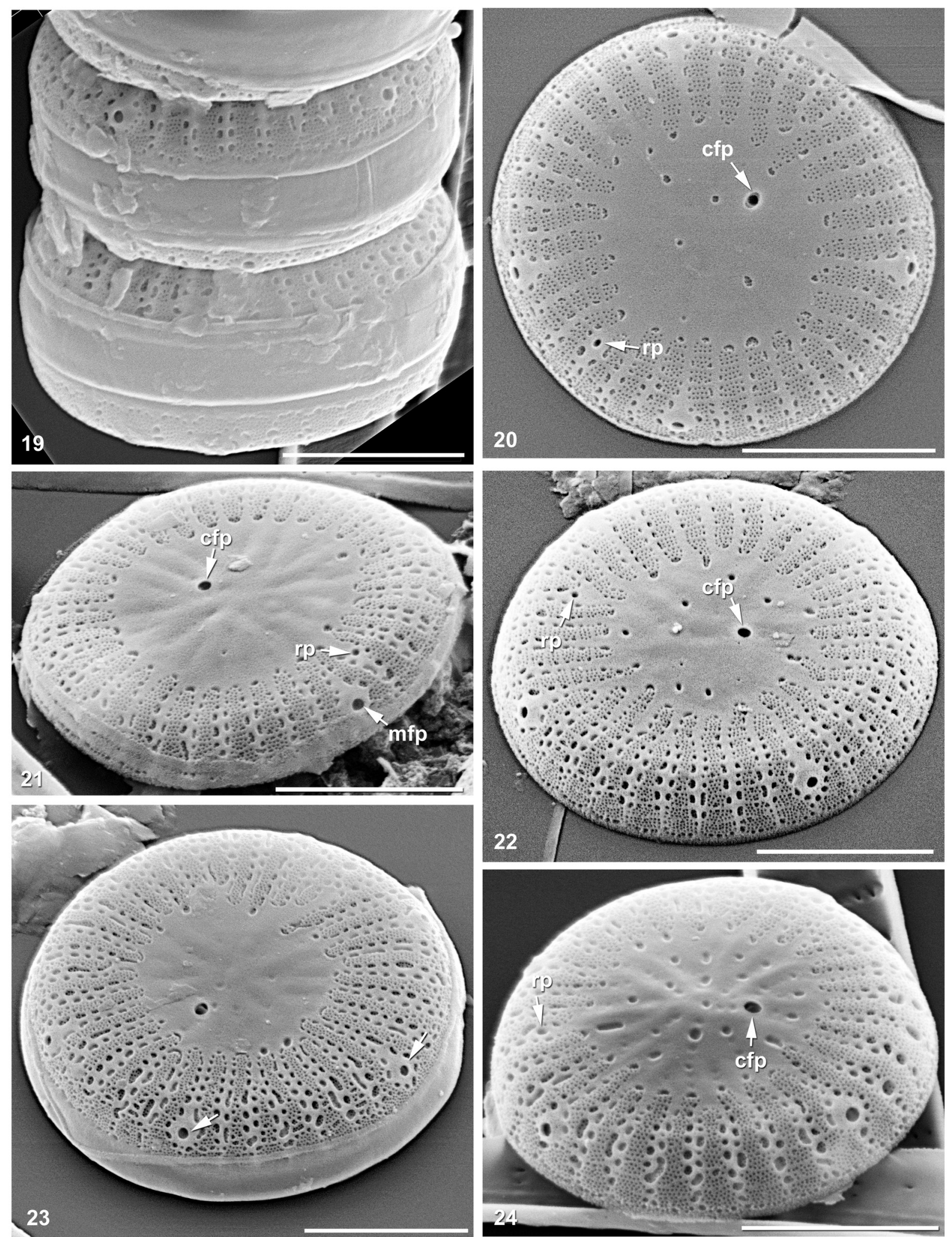

Figs 19-24. Cyclotella hinziae sp. nov. SEM, type material, Lake Schliersee (Bavaria, Germany), plankton 31 March 2014: (19-24) external views; (19) girdle view of a short tilted chain of cells; (20-24) valve exterior of valves; (20-22,24) note central and marginal valve part with central fultoportula (cfp) and a rimoportula (rp) situated opposite; (23) note outer openings of marginal fultoportulae (arrows) as simple large pori inside small smooth circular fields; $(20,22,24)$ note pori in the valve central part. Scale bar $2 \mu \mathrm{m}$. 

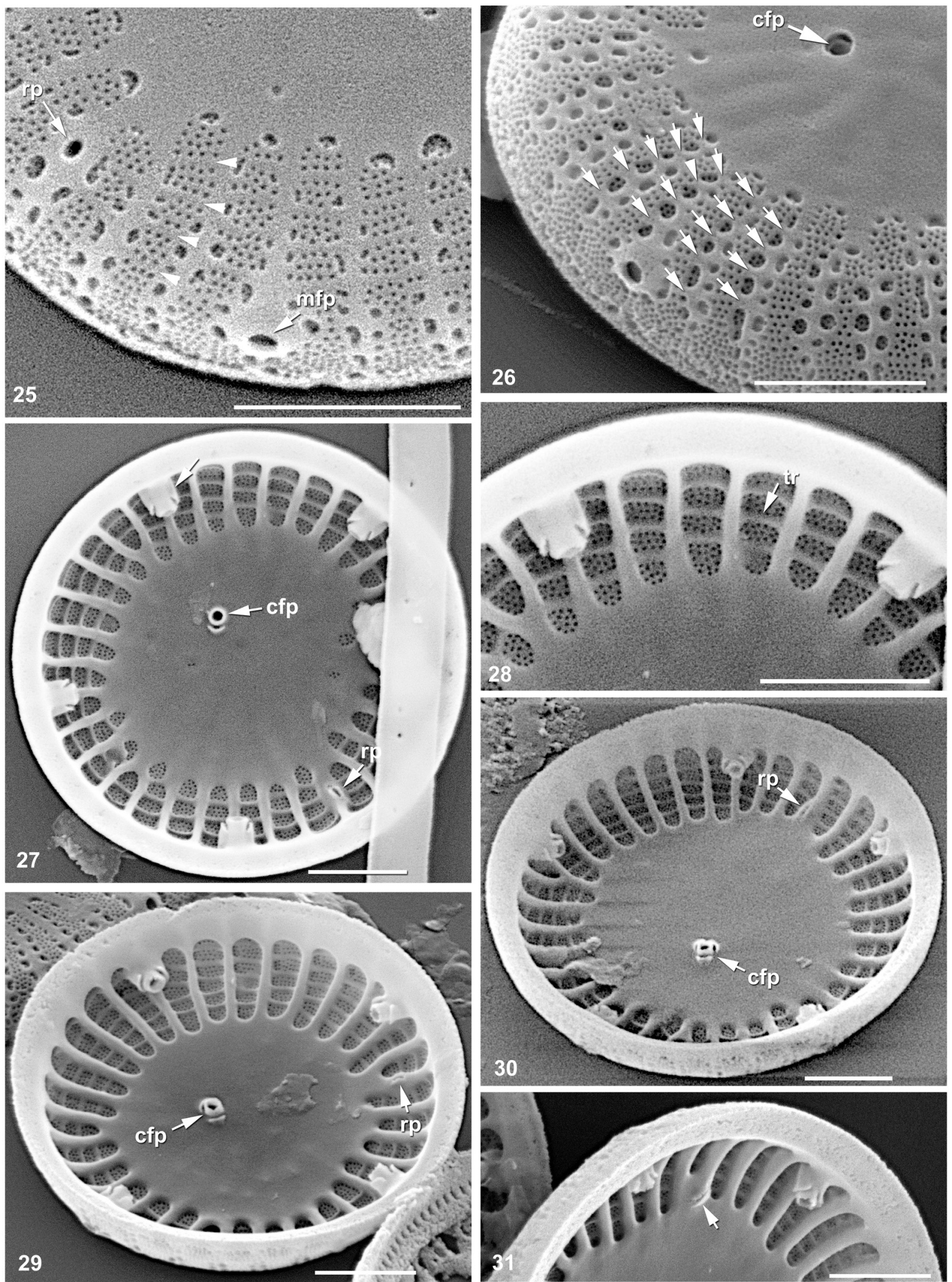

Figs 25-31. Cyclotella hinziae sp. nov. SEM, type material, Lake Schliersee (Bavaria, Germany), plankton 31 March 2014: (25, 26) details of the valve margin exterior, note the external bridges between the striae (arrows) internally corresponding to trabeculi, (26) note depressed external tube of central fultoportula (cfp); (27-31) valve interior views, (27) note long internal central tube of marginal fultoportula (arrow) with 2 long satellite pore covers oriented laterally, internal opening of central fultoportula (cfp) with a single satellite pore and sessile labium of rimoportula (rp) situated opposite on a rib, (28) detail from Fig. 27, note circumferentially oriented trabeculae (tr) in the valve marginal part with small irregularly arranged pori between them, (29) note the internal opening of central fultoportula (cfp) with 2 satellite pori, (30) note the internal opening of central fultoportula (cfp) with 3 satellite pori, (31) note the internal sessile labium of rimoportula situated near the central part. Scale bar $1 \mu \mathrm{m}$. 


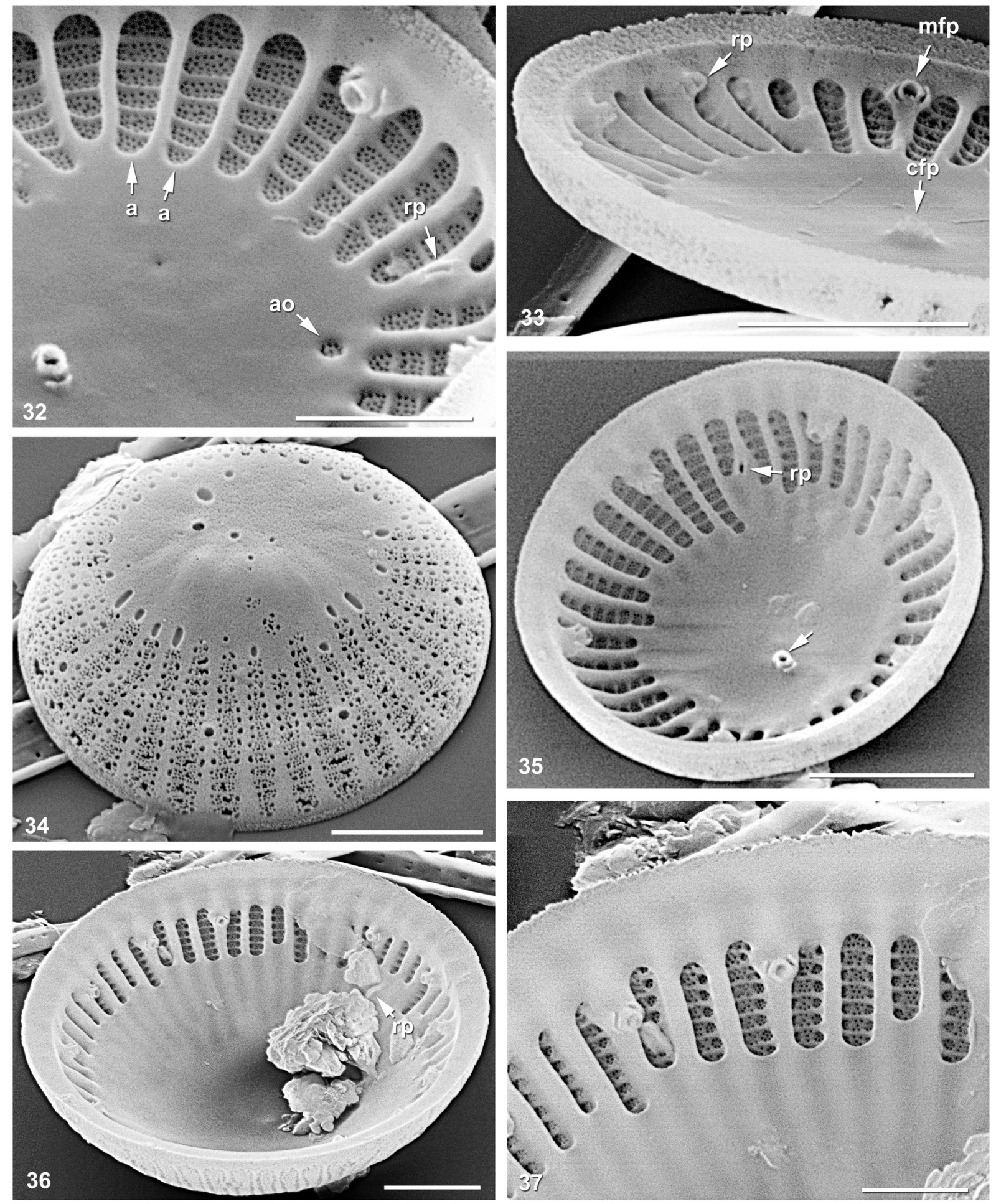

Figs 32-37. Cyclotella hinziae sp. nov. SEM, Type material, Lake Schliersee (Bavaria, Germany), plankton 31 March 2014: (32, 33) valve interior views, (32) detail of a valve marginal part; note internal alveolar openings (a), one small extra alveolar opening (ao) and an internal sessile labium of rimoportula (rp) situated in the middle of a costa, (33) detail of a valve marginal part with an internal projection of marginal fultoportula $(\mathrm{mfp})$ with two satellite pori oriented laterally (circumferentially), central fultoportula (cfp) and internal sessile labium of rimoportula (rp) situated near the valve edge; (34-37) initial valves, (34) external view of a valve; note partially transversally undulate central part; (35-37) valve interiors, (35) note internal sessile labium of rimoportula (rp) and an internal projection of central fultoportula (arrow), (36) note internal sessile labium of rimoportula (rp) located below the internal openings of alveoli, (37) detail from Fig. 36, note transversal trabeculi inside alveoli. Scale bar $1 \mu \mathrm{m}(32,37), 2 \mu \mathrm{m}(33-36)$. 

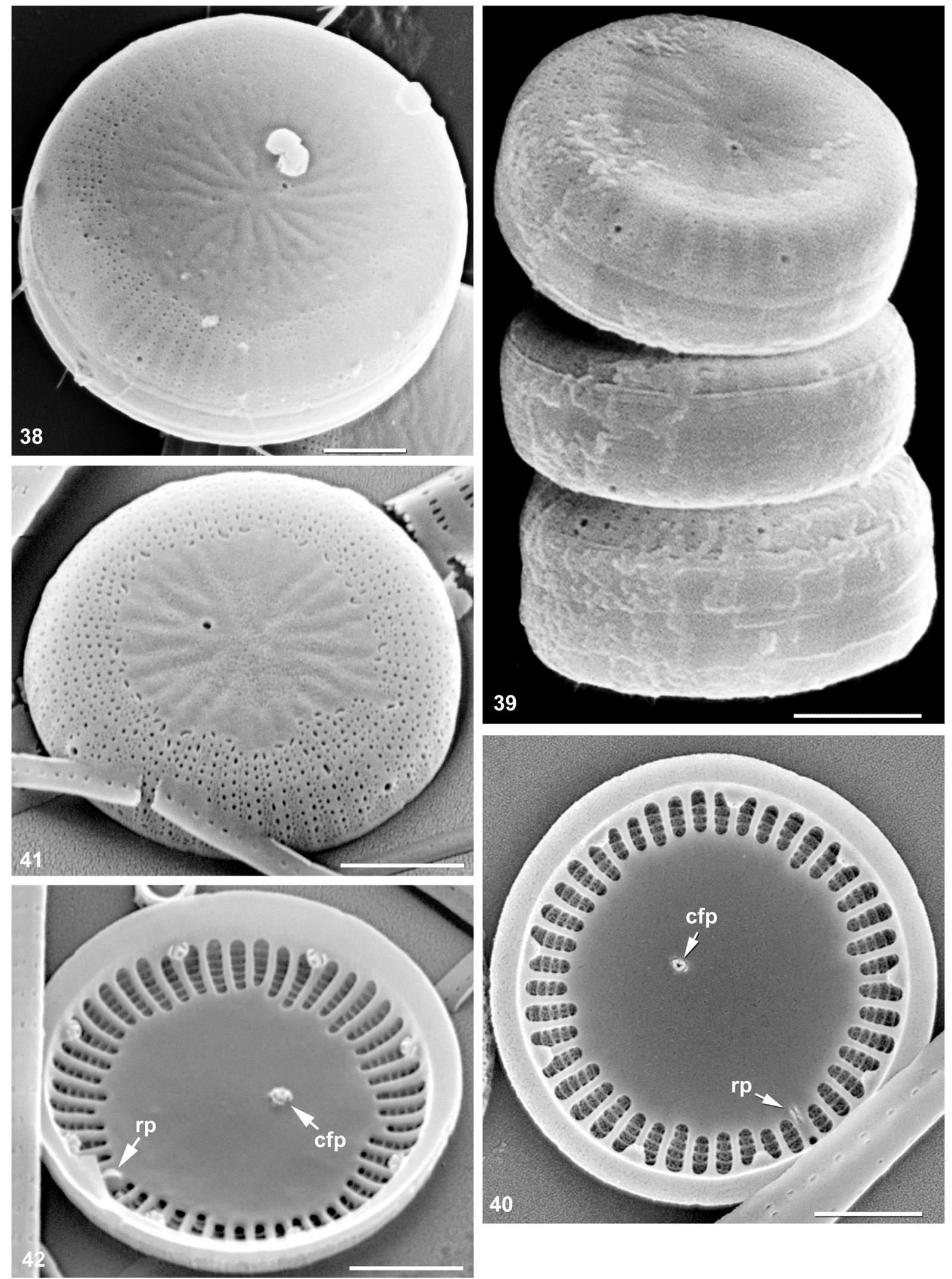

Figs 38-42. Cyclotella hinziae sp. nov., SEM: (38) Lake Schliersee (Bavaria, Germany), plankton 6 May 1997; (39) Lake Schliersee (Bavaria, Germany), plankton 5 Nov 2001; (40) Lake Schliersee (Bavaria, Germany), plankton 21 Aug 2006; (41, 42) Lake Schliersee (Bavaria, Germany), plankton 25 May 2010; $(38,39,41)$ exterior of tilted valves, note finely radially warped valve central parts; $(40,42)$ valve internal views; note internal projections of central fultoportulae (cfp), internal sessile labia of rimoportulae (rp) and concentric transversal rings of trabeculae inside alveoli. Scale bar $2 \mu \mathrm{m}$. 
and Discostella. - Fottea 10, Supplement: 1- 498.

Hustedt, F. (1952): Neue und wenig bekannte Diatomeen. IV. - Botaniska Notiser 1952, Häfte 4: 366-410.

John, J. \& Economou-Amilli, A. (1990): Cyclotella cretica, a new species of diatom from the island of Crete, Greece. - Diatom Research 5: 43-50.

Kiss, K.T.; KleE, R. \& Hegewald, E. (1999): Reinvestigation of the original material of Cyclotella ocellata PANTOCSEK (Bacillariophyceae). - Algological Studies 93: 39-53.

Kiss, K.T.; Ács, É.; Szabo, K.É.; Miracle, R.M. \& Vicente, E. (2007): Morphological observations on C. distinguenda HUSTEDT and $C$. delicatula HUSTEDT from a core sample of a meromictic karstic lake of Spain (Lake La Cruz) with aspects of their ecology. Diatom Research 22: 287-308.

Krammer, K. \& Lange-Bertalot, H. (1991): Bacillariophyceae, 3. Teil: Centrales, Fragilariaceae, Eunotiaceae. - In: Ettl, H.; Gerloff, J.; Heynig, H. \& MollenHAUER, D. (eds): Süsswasserflora von Mitteleuropa, vol. 2/3. -576 pp., Gustav Fischer Verlag, Stuttgart, Jena.

Nixdorf, B.; Hemm, M.; Hoffmann, A. \& Richter, P. (2003): „Dokumentation von Zustand und Entwicklung der wichtigsten Seen Deutschlands: Teil 11 Bayern". Abschlussbericht, F\&E Forhaben FKZ 29924274 Brandenburgische Technische Universtät Cottbus.

Pantocsek, J. (1901): Die Kieselalgen oder Bacillarien des Balaton. - In: Resultate der wissenschaftlichen Erforschung des Balatonsees. 2. Band. Anhang zur 2. Section des 2. Theiles. Budapest.

Ross, R.; Cox, E.J.; Karayeva, N.I.; MANN, D.G.; PAdDOCK, T.B.B.; Simonsen, R. \& Sims, P. (1979): An amended terminology for the siliceous components of the diatom cell. - Nova Hedwigia Beiheft 64: 513-533.
Round, F.E.; Crawford, R.M. \& Mann D.G. (1990): The Diatoms. Biology and morphology of the genera. 747 pp., Cambridge University Press, Cambridge.

SCHEFfler, W. (1994): Cyclotella pseudocomensis nov. sp. (Bacillariophyceae) aus Norddeutschen Seen. - Diatom Research 9: 355-369.

Scheffler, W. \& Morabito, G. (2003): Topical observations on centric diatoms (Bacillariophyceae, Centrales) of Lake Como (N. Italy). - Journal of Limnology 62: 47-60.

Scheffler, W.; Nicklisch, A. \& Hepperle, D. (2003): Dimorphism in Cyclotella pseudocomensis (Heterokontophyta, Bacillariophyceae) as revealed by morphological, ecological and molecular methods. - Archiv für Hydrobiologie, Special Issue Advances in.Limnology 58: 157-173.

SCheffler, W.; Nicklisch, A. \& SchöNfelder, I. (2005): Beiträge zur Morphologie. Ökologie und Ontogenie der planktischen Diatomee Cyclotella comensis Grunow. Untersuchungen an historischem und rezentem Material. - Diatom Research 20: 171-200.

Theriot, E. \& Serieyssol, K.K. (1994): Phylogenetic systematics as a guide to understanding features and potential morphological characters of the centric diatom family Thalassiosiraceae. - Diatom Reseach 9: $429-450$.

VAn HeURCK, H. (1880-1885): Synopsis des Diatomées de Belgique. Atlas. - Taf. 78-103 (1882), 235 pp., Anvers 1885 .

(C) Czech Phycological Society (2015)

Received April 1, 2015

Accepted June 6, 2015 